\title{
Analisis Kemampuan Representasi Matematis Siswa pada Materi Statistika
}

\author{
Nuurun Fajriah ${ }^{1}$ Citra Utami $^{2}$ Mariyam $^{3}$ \\ STKIP Singkawang, Singkawang, Indonesia \\ Nuurunfajriah@gmail.com ${ }^{1}$, Citrautami1990@gmail.com ${ }^{2}$, Mariyam.1804.88@gmail.com ${ }^{3}$
}

Keywords :

Analisis, Kemampuan Representasi

Matematis, Statistika

\begin{abstract}
Penelitian ini bertujuan untuk mendeskripsikan tingkat kemampuan representasi matematis siswa, kesalahan siswa dalam menyelesaikan soal statistika berdasarkan indikator kemampuan representasi matematis siswa, dan faktor yang mempengaruhi siswa melakukan kesalahan dalam menyelesaikan soal statistika berdasarkan indikator kemampuan representasi matematis siswa pada kelas XI di SMA Negeri 5 Singkawang. Penelitian ini menggunakan description research. Subjek penelitian ini adalah 15 siswa kelas XI IPS di SMA Negeri 5 Singkawang. Instrument soal yang digunakan dalam penelitian ini berupa 3 buah soal tes tertulis yang mengacu pada indikator kemampuan representasi matematis siswa. Teknik analisis data yang digunakan dalam penelitian ini adalah teknik analisis interaktif yang terdiri atas tiga komponen yaitu reduksi data, penyajian data, dan penarikan kesimpulan. Hasil penelitian ini, menunjukkan bahwa (1) Tingkat kemampuan representasi matematis siswa sebesar 54,6\% dengan kategori sedang. (2) Kesalahan dalam menyelesaikan soal statistika yang meliputi kesalahan konsep (salah dalam memahami makna soal), kesalahan prinsip (salah dalam penarikan kesimpulan dalam menentukan jawaban akhir soal, salah dalam menggunakan aturan-aturan dalam rumus matematika), dan kesalahan operasi (salah dalam menggunakan operasi dalam matematika baik penjumlahan, pengurangan, pembagian, maupun perkalian). (3) Faktor yang mempengaruhi kesalahan siswa dalam menyelesaikan soal meliputi faktor kesalahan konsep (siswa tidak memahami soal yang diteskan), faktor kesalahan prinsip (salah dalam penarikan kesimpulan untuk menentukan jawaban akhir soal, tidak menggunakan aturan-aturan dalam rumus matematika), dan faktor kesalahan operasi (ketidak cermatan menentukan hasil perhitungan baik penjumlahan, pengurangan, pembagian, maupun perkalian).
\end{abstract}




\section{PENDAHULUAN}

Matematika sebagai wahana pendidikan memegang peran penting dalam pendidikan. Belajar matematika merupakan salah satu sarana berpikir ilmiah dan logis serta mempunyai peran penting dalam upaya meningkatkan kualitas sumber daya manusia. Matematika juga sebagai ilmu universal yang mendasari perkembangan teknologi modern, mempunyai peran penting dalam berbagai disiplin ilmu dan mengembangkan daya pikir manusia. Buyung, B., \& Nirawati, R. (2018) Dalam mengembangkan daya pikir manusia diperlukan beberapa proses keterampilan dalam belajar matematika.

Menurut National Council Of Teacher Of Mathematics (NCTM dalam Abdullah, 2012) menyatakan bahwa proses pembelajaran matematika meliputi kemampuan pemecahan masalah, kemampuan komunikasi, kemampuan koneksi, kemampuan penalaran, dan kemampuan representasi. Dari sumber tersebut diketahui bahwa kemampuan representasi adalah kemampuan yang harus dimiliki siswa dalam proses pembelajaran. Representasi (penyajian) merupakan metode yang sangat baik untuk menyajikan ide-ide dan hubungan dalam matematika. Bentuk penyajian seperti simbol, bagan, dan grafik harus dipahami siswa untuk mengomunikasikan ide-ide di dalam matematika kepada orang lain.

Selain itu kemampuan representasi merupakan salah satu komponen penting untuk mengembangkan kemampuan berfikir siswa, karena pada proses pembelajaran matematika siswa perlu mengaitkan materi yang sedang dipelajari serta merepresentasikan ide/gagasan dalam berbagai macam cara. Hal ini sejalan dengan pendapat Jones (dalam Imron, 2015) yang menyatakan bahwa terdapat tiga alasan mengapa representasi perlu dikembangkan dalam pembelajaran matematika, yaitu 1) kelancaran dalam melakukan translasi di antara berbagai jenis representasi yang berbeda merupakan kemampuan dasar yang perlu dimiliki siswa untuk membangun suatu konsep dan berpikir matematis, 2) ide-ide matematis yang disajikan guru melalui berbagai representasi akan memberi pengaruh yang sangat besar terhadap siswa dalam mempelajari matematika, 3) siswa membutuhkan latihan dalam membangun representasinya sendiri sehingga memiliki kemampuan dan pemahaman konsep yang baik dan fleksibel yang dapat digunakan dalam penyelesaian masalah. Dari kutipan tersebut jelas bahwa representasi memiliki peranan penting dalam pembelajaran matematika karena dengan representasi peserta didik akan lebih mudah dalam mengomunikasikan ide-ide matematis sehingga masalahmasalah matematis yang diberikan dapat diselesaikan dengan baik. Penggunaan representasi oleh siswa dapat menjadikan gagasan-gagasan matematis lebih konkrit dan membantu siswa untuk memecahkan suatu masalah yang dianggap rumit dan kompleks menjadi lebih sederhana. Selain itu dengan dikuasainya kemampuan representasi dengan baik, maka akan diikuti dengan kemampuan pemahaman konsep yang baik pula.

Hal ini sejalan dengan pendapat Sabirin (2014:35) yang menyatakan bahwa representasi dapat memberi kelancaran siswa dalam membangun suatu konsep dan berfikir matematis serta untuk memiliki kemampuan dan pemahaman konsep yang kuat dan fleksibel yang dibangun oleh guru melalui representasi matematis. Pentingnya kemampuan representasi matematis juga dapat dilihat dari standar representasi yang ditetapkan oleh NCTM (dalam Walle, 2008:5) satu diantaranya kemampuan representasi matematis yang dapat dikuasai siswa selama pembelajaran di sekolah adalah menciptakan dan menggunakan representasi untuk mengorganisir, mencatat, dan mengomunikasikan ide-ide matematis. Dengan demikian, kemampuan representasi matematis diperlukan siswa untuk menemukan dan membuat suatu alat atau cara berfikir dalam mengomunikasikan gagasan matematis dari yang sifatnya abstrak menuju konkret, sehingga lebih mudah untuk dipahami.

Meskipun kemampuan representasi matematis merupakan hal yang sangat penting dalam pembelajaran matematika, namun pada kenyataannya masih banyak guru yang mengesampingkan kemampuan representasi matematis siswa. Padahal dengan kemampuan representasi matematis yang baik, siswa akan lebih mudah memahami konsep yang sedang dipelajarinya. Hasil studi pendahuluan 
Hudiono (dalam Muthmainnah, 2014) menyebutkan bahwa menurut guru, representasi matematis berupa grafik, tabel, dan gambar hanya merupakan pelengkap pembelajaran saja dan guru jarang memperhatikan perkembangan kemampuan representasi matematis siswa. Hal tersebut mengindikasi bahwa dalam pembelajaran matematika kemampuan representasi kurang diperhatikan sehingga mengakibatkan rendahnya kemampuan representasi matematis siswa.

Rendahnya kemampuan representasi matematis siswa dapat dilihat dari catatan Trends in International Mathematics and Science Study (TIMSS, 2011) sebuah lembaga yang mengukur dan membandingkan kemampuan matematika siswa-siswa antar negara, penguasaan matematika siswa negara Indonesia menempati peringkat ke- 38 dari 42 negara. Rerata skor yang diperoleh siswa-siswi Indonesia adalah 386 dan masih berada di bawah rata-rata skor internasional yaitu 500. Rerata skor ini pun masih jauh di bawah rerata negara ASEAN lainnya seperti Singapura, Malaysia, dan Thailand. Soal-soal yang diujikan dalam TIMSS 2011 ini satu diantaranya mencakup kognitif pengetahuan kemampuan representasi matematis pada materi statistika. Adapun contoh soal TIMSS mengenai materi statistika dapat dilihat pada Gambar 1 berikut ini.

Of the 400 students in a school, 50 plan to go to university, 100 to a polytechnic school, 150 to a business college, and the reminder plan to enter workforce. Use the circle below to make a plo chart showing the proportions of students planning to do each of these. Put labels on your chart.

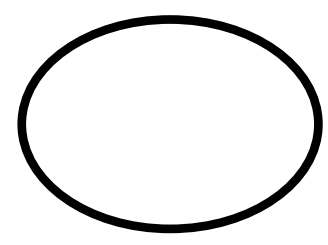

\section{Gambar 1 Soal Studi TIMSS Materi Statistika}

Topik utama dari soal pada Gambar 1 adalah data organization and representation. Soal ini termasuk ke dalam jenis representasi visual yang dalam hal ini meminta siswa untuk menyajikan data dari suatu representasi ke representasi yang lain. Soal pada Gambar 1 meminta siswa menyajikan representasi berbentuk kata-kata ke dalam representasi diagram lingkaran. Persentase siswa Indonesia yang menjawab benar soal Gambar 1 tersebut adalah sebanyak 26\%, dan jumlah ini masih berada di bawah rata-rata internasional yaitu $45 \%$. Susilawati (2014) menyebutkan kemungkinan penyebab kesalahan siswa salah satunya adalah siswa tidak memahami maksud dari soal dan kurangnya pemahaman siswa terhadap penyajian data dalam bentuk diagram. Berdasarkan pemaparan data yang diperoleh dari hasil TIMSS 2011 di atas, dapat disimpulkan bahwa rendahnya prestasi matematika Indonesia tersebut mencakup rendahnya kemampuan representasi matematis.

Selain berdasarkan hasil TIMSS, rendahnya kemampuan representasi juga terlihat pada hasil penelitian yang dilakukan oleh Aiman (2014). Hasil penelitian menunjukkan bahwa dari beberapa indikator representasi matematis yang diujikan, rata-rata perolehan skor siswa yang mendapat skor baik kurang dari 33\%. Rendahnya perolehan skor tersebut dipengaruhi oleh beberapa faktor yaitu siswa kurang memahami soal, siswa kurang terampil dalam membuat gambar untuk menyelesaikan suatu permasalahan, siswa kurang terampil dalam membuat model matematika, dan siswa tidak dapat membuat kesimpulan secara tepat. Selain itu, hasil penelitian Mariyam (2016) menunjukkan bahwa rendahnya pencapaian hasil studi tersebut disebabkan karena kemampuan siswa di Indonesia dalam menemukan solusi atau mencari alternatif jawaban dari suatu permasalahan masih terfokus pada satu cara atau penyajian yang terbatas dan bersifat prosedural, karena diduga siswa masih kurang dapat mengomunikasikan permasalahan yang diberikan dan kurang dapat merepresentasikan kedalam berbagai bentuk, akibatnya siswa mengalami kesulitan dalam menemukan solusi. 
Kemampuan representasi matematis siswa yang rendah tersebut menunjukkan bahwa kemampuan representasi matematis penting bagi siswa dalam memudahkan mempelajari materi matematika. Salah satu materi pokok yang penting untuk dipelajari yaitu materi statistika. Namun kenyataan menunjukkan bahwa banyak diantara siswa-siswa khususnya siswa sekolah menengah atas tidak dapat menguasai materi statistika dengan benar. Hal ini dibuktikan dengan penelitian terdahulu yang menyangkut dengan penguasaan siswa sekolah menengah atas terhadap materi statistika yaitu hasil penelitian dari Pujiastuti (2008) menunjukkan bahwa sebagian besar siswa masih lemah dalam menyampaikan ide melalui lisan atau teks tertulis. Penjelasan tersebut memberikan penguatan bahwa representasi yang tidak tepat menyebabkan kesalahan dalam penyelesaian masalah, misalnya ketika mengubah soal cerita kedalam model matematis.

Hal yang sama juga terjadi di SMA Negeri 5 Singkawang, berdasarkan wawancara dengan guru bidang studi mata pelajaran matematika disekolah tersebut diketahui bahwa hasil belajar siswa pada materi statistika masih tergolong rendah. Rendahnya hasil belajar siswa pada materi statistika tersebut dianggap sulit oleh siswa, hal tersebut dapat dilihat dari hasil ulangan harian siswa yang menunjukkan bahwa sekitar 70\% siswa belum mencapai nilai KKM, dengan Kriteria Ketuntasan Minimum (KKM) sebesar 65. Hal tersebut terungkap dari wawancara dengan guru matematika yang mengungkapkan bahwa rendahnya hasil belajar siswa pada materi statistika dikarenakan terdapat kesalahan siswa dalam menyelesaikan soal diantaranya lemahnya siswa dalam memahami soal yang diberikan, serta kurangnya kemampuan siswa dalam menyajikan kembali data kedalam bentuk gambar atau tabel.

Materi yang dipilih dalam penelitian ini adalah materi statistika, dimana materi tersebut telah diajarkan di SMA Negeri 5 Singkawang. Sedangkan materi statistika yang akan dikaji dalam penelitian ini, dikhususkan pada submateri tabel distribusi frekuensi, median dan modus. Berdasarkan uraian di atas, rendahnya hasil belajar siswa pada materi statistika menjadi pertimbangan peneliti dalam memilih materi ini dikarenakan masih banyak siswa yang tidak menguasai materi statistika terutama pada submateri tabel distribusi frekuensi, median dan modus. Hal ini dikarenakan tabel distribusi frekuensi, median, dan modus memiliki konsep rumus yang beragam sehingga menyulitkan siswa dalam menyelesaikan soal yang diberikan.Berdasarkan uraian di atas, peneliti tertarik untuk melakukan penelitian terhadap kemampuan representasi matematis siswa SMA Negeri 5 Singkawang kelas XI pada materi statistika.

\section{METODE}

Jenis penelitian yang digunakan dalam penelitian ini adalah penelitian deskriptif atau description research dengan pendekatan kualitatif. Menurut Mahmud (dalam Sugiyono, 2012: 100) metode deskriptif merupakan suatu penelitian yang diupayakan untuk mengamati permasalahan secara sistematis dan akurat mengenai fakta dan sifat objek tertentu. Sedangkan model yang digunakan adalah model kualitatif. Menurut Sugiyono (2012: 9) penelitian kualitatif adalah metode penelitian yang berlandaskan pada filsafat postpositive yang digunakan untuk meneliti pada kondisi obyek yang alamiah (sebagai lawannya eksperimen) dimana peneliti adalah sebagai instrumen kunci, teknik pengumpulan data dilakukan secara dokumentasi dan triangulasi (gabungan), analisis data bersifat induktif/kualitatif dan hasil penelitian kualitatif lebih menekankan makna daripada generalisasi. Tujuan dari penelitian ini adalah untuk mencari informasi serta mendeskriptifkan tingkat kemampuan representasi matematis siswa, kesalahan siswa dalam menyelesaikan soal, dan faktor yang mempengaruhi siswa dalam menyelesaikan soal pada materi statistika kelas XI SMA Negeri 5 Singkawang.

Teknik pengumpulan data dalam penelitian ini adalah teknik pengukuran yaitu dengan memberikan tiga soal tes tertulis (essay) yang mencakup tiga indikator kemampuan representasi matematis yaitu (1) menyajikan kembali data atau informasi kedalam bentuk tabel dan diagram, (2) menyelesaikan masalah yang melibatkan ekspresi matematis, (3) menyusun cerita dan menyatakan suatu pernyataan 
atau ide matematika dengan menggunakan kata-kata atau teks tertulis. Untuk menghitung hasil tes tersebut menggunakan teknik penskoran yaitu dengan memberikan siswa skor pada setiap butir soal yang dijawab benar sesuai dengan tabel penskoran dan kunci jawaban. Teknik pengumpulan data yang kedua yaitu teknik komunikasi langsung yaitu dengan wawancara (interview) untuk mengetahui faktor yang mempengaruhi siswa melakukan kesalahan dalam menyelesaikan soal statistika berdasarkan indikator kemampuan representasi matematis.

Teknik analisis data yang digunakan dalam penelitian ini adalah teknik analisis interaktif yang dikembangkan oleh Miles dan Huberman (dalam Sugiyono, 2013: 246). Teknik analisis interaktif terdiri atas tiga komponen yaitu reduksi data, penyajian data, dan penarikan kesimpulan. Instrumen pengumpulan data berupa tes terlebih dulu di uji validitas, reliabilitas, daya pembeda dan tingkat kesukarannya. Adapun hasil perhitungan validitas, reliabilitas, daya pembeda, dan indeks kesukaran dapat dilihat pada Tabel 1. berikut ini.

Tabel 1 Perhitungan Uji Coba Soal

\begin{tabular}{ccccc}
\hline $\begin{array}{c}\text { No } \\
\text { Soal }\end{array}$ & Validitas Soal & $\begin{array}{c}\text { Reliabilita } \\
\text { s }\end{array}$ & $\begin{array}{c}\text { Daya } \\
\text { Pembeda }\end{array}$ & $\begin{array}{c}\text { Indeks } \\
\text { Kesukaran }\end{array}$ \\
\hline 1 & 0,88 & & 0,46 & 0,68 \\
& (Sangat Tinggi) & & $($ Baik) & (Sedang) \\
2 & 0,85 & 0,83 & 0,26 & 0,64 \\
& (Sangat Tinggi) & (Sangat & (Cukup) & $($ Sedang) \\
3 & 0,87 & Tinggi) & 0,33 & 0,69 \\
& (Sangat Tinggi) & & (Cukup) & (Sedang) \\
\hline
\end{tabular}

Berdasarkan analisis secara keseluruhan terhadap uji coba soal tes kemampuan representasi matematis yang dilaksanakan di SMA Negeri 6 Singkawang perangkat soal yang dihasilkan rata-rata memiliki validitas soal sangat tinggi, reliabilitasnya sangat tinggi, serta daya pembeda dan tingkat kesukarannya tergolong cukup. Hal ini menunjukkan bahwa soal yang dihasilkan sudah memenuhi kriteria tepat dan praktis, sehingga soal-soal tersebut dapat dikatakan layak digunakan. Hal ini senada dengan penelitian yang dilakukan oleh Lewi (2008) dan Suandito (2008) yang menyatakan bahwa soal dikatakan layak jika memenuhi kriteria valid dan praktis, yang mana valid menunjukkan bahwa soal tersebut tepat mengukur kemampuan siswa.

\section{HASIL DAN PEMBAHASAN}

Hasil penelitian diperoleh dari setiap tahapan pelaksanaan kegiatan, dengan istrumen berupa tes dan wawancara. Hasil tersebut digunakan untuk menjawab rumusan masalah dalam penelitian ini yaitu bagaimanakah tingkat kemampuan representasi matematis siswa dalam menyelesaikan soal materi statistika kelas XI SMA Negeri 5 Singkawang, apa sajakah kesalahan siswa dalam menyelesaikan soal representasi matematis materi statistika kelas XI SMA Negeri 5 Singkawang, dan apa sajakah faktor yang mempengaruhi kesalahan siswa dalam menyelesaikan soal representasi matematis materi statistika kelas XI SMA Negeri 5 Singkawang.

\section{Tingkat kemampuan representasi matematis siswa}

Pada tahap pertama yaitu tentang tingkat kemampuan representasi matematis siswa diperoleh berdasarkan hasil tes tertulis (essay) sebanyak 3 soal materi statistika. Soal tes tersebut mengandung 3 indikator yaitu menyajikan kembali data atau informasi kedalam bentuk tabel dan diagram, menyelesaikan masalah yang melibatkan ekspresi matematis, menyusun cerita dan menyatakan suatu pernyataan atau ide matematika dengan menggunakan kata-kata atau teks tertulis. Data tersebut diperoleh melalui pemberian instrumen kepada siswa berupa tes kemampuan representasi matematis. Setelah pemberian instrumen tes, hasil tes siswa dikumpulkan maka jawaban dari tes siswa tersebut 
akan dikoreksi dan ditabulasi. Selanjutnya, dari tabulasi jawaban siswa ditentukan berdasarkan kriteria tingkat kemampuan.

Kemampuan representasi matematis siswa tersebut, akan diberi kriteria yaitu tinggi, sedang, dan rendah. Kemudian dari hasil tes siswa tersebut, dapat ditabulasikan menjadi tingkat kemampuan representasi matematis siswa per kelompok siswa dan per indikator. Tingkat kemampuan representasi matematis siswa per kelompok dapat dilihat dengan mengelompokkan siswa menjadi 3 kelompok yaitu siswa kelompok atas, tengah, dan bawah. Sedangkan tingkat kemampuan representasi matematis siswa per indikator, dapat dilihat dari ketiga indakator kemampuan representasi matematis dalam peneletian ini. Berikut tabulasi perhitungan tingkat kemampuan representasi matematis siswa secara keselurahan akan disajikan secara ringkas dalam Tabel 2 sebagai berikut.

Tabel 2 Perhitungan Tingkat Kemampuan Representasi Matematis Keseluruhan Siswa Kriteria Banyak Siswa Persentase Rata-rata Nilai

\begin{tabular}{cccc}
\hline Tinggi & 3 & $20 \%$ & \\
Sedang & 4 & $27 \%$ & $54,6 \%$ \\
Rendah & 8 & $53 \%$ & Sedang \\
\hline Jumlah & 15 & & \\
\hline
\end{tabular}

Dari Tabel 2. di atas diketahui bahwa tingkat kemampuan representasi matematis siswa dengan kriteria tinggi sebanyak 3 siswa dengan persentase $20 \%$, tingkat kemampuan representasi matematis siswa dengan kriteria sedang sebanyak 4 siswa dengan persentase $27 \%$, dan tingkat kemampuan representasi matematis siswa dengan kriteria rendah sebanyak 8 siswa dengan persentase 53\%. Diketahui bahwa tingkat kemampuan representasi matematis siswa pada materi statistika kelas XI IPS 2 SMA Negeri 5 Singkawang tergolong rendah dengan nilai rata-rata keseluruhan tingkat kemampuan representasi matematis siswa sebesar 54,6\% dengan kategori sedang. Sedangkan, untuk mengetahui tingkat kemampuan representasi matematis siswa per kelompok, dapat dilihat pada Tabel 3 berikut.

Tabel 3 Rekapitulasi Tingkat Kemampuan

Representasi Matematis Siswa Per Kelompok

\begin{tabular}{ccc}
\hline Kelompok Siswa & $\begin{array}{c}\text { Rata-rata \% Skor } \\
\text { Kelompok Siswa }\end{array}$ & Kriteria \\
\hline Kelompok Atas & $76,1 \%$ & Tinggi \\
Kelompok Tengah & $52,3 \%$ & Sedang \\
Kelompok Bawah & $35,1 \%$ & Rendah \\
\hline
\end{tabular}

Dari Tabel 3. di atas terlihat bahwa tingkat kemampuan representasi matematis siswa berdasarkan masing-masing kelompok diketahui bahwa pada siswa kelompok atas diperoleh persentase sebesar $76,1 \%$ dengan kriteria tinggi, siswa kelompok tengah diperoleh persentase sebesar 52,3\% dengan kriteria sedang, dan untuk siswa kelompok bawah diperoleh persentase sebesar 35,1\% dengan kriteria rendah. Berdasarkan data di atas dapat disimpulkan bahwa tingkat kemampuan representasi matematis siswa untuk kelompok atas lebih tinggi dibandingkan dengan kelompok tengah dan kelompok bawah. Untuk mengetahui presentase tingkat kemampuan representasi matematis siswa per indikator dapat dilihat pada Tabel 4 sebagai berikut. 
Tabel 4 Tingkat Kemampuan Representasi Matematis Siswa Per Indikator

\begin{tabular}{|c|c|c|c|}
\hline $\begin{array}{l}\text { No } \\
\text { Soal }\end{array}$ & $\begin{array}{c}\text { Indikator Kemampuan Representasi } \\
\text { Matematis }\end{array}$ & \multicolumn{2}{|c|}{$\begin{array}{l}\text { Rata-rata } \\
\text { Per Indikator Kriteria } \\
\quad(\%)\end{array}$} \\
\hline 1 & $\begin{array}{l}\text { Menyajikan kembali data atau informasi } \\
\text { kedalam bentuk tabel atau diagram }\end{array}$ & $70 \%$ & Sedang \\
\hline 2 & $\begin{array}{l}\text { Menyelesaikan masalah yang melibatkan } \\
\text { ekspresi matematis }\end{array}$ & $45,2 \%$ & Rendah \\
\hline 3 & $\begin{array}{c}\text { Menyusun cerita dan menyatakan suatu } \\
\text { pernyataan atau ide matematika dengan kata-kata atau } \\
\text { teks tertulis }\end{array}$ & $53,3 \%$ & Sedang \\
\hline
\end{tabular}

Dari Tabel 4 di atas, tingkat kemampuan representasi matematis siswa berdasarkan masing-masing indikator diketahui bahwa pada indikator menyajikan kembali data atau informasi kedalam bentuk tabel atau diagram diperoleh persentase sebesar 70\% dengan kriteria sedang, untuk indikator menyelesaikan masalah yang melibatkan ekspresi matematis diperoleh persentase sebesar 45,2\% dengan kriteria rendah, dan untuk indikator menyusun cerita dan menyatakan suatu pernyataan atau ide matematika dengan kata-kata atau teks tertulis diperoleh persentase sebesar 53,3\% dengan kriteria sedang. Berdasarkan data di atas dapat disimpulkan bahwa tingkat kemampuan representasi matematis siswa pada indikator menyajikan kembali data atau informasi kedalam bentuk tabel atau diagram dan menyusun cerita dan menyatakan suatu pernyataan atau ide matematika dengan kata-kata atau teks tertulis tergolong sedang. Sedangkan, untuk indikator menyelesaikan masalah yang melibatkan ekspresi matematis tergolong rendah.

Hal ini sejalan dengan penelitian Rahma (2014: 33) yang menyatakan bahwa kriteria tingkat kemampuan representasi matematis siswa terdiri dari tiga kriteria yaitu kriteria tinggi, sedang, dan rendah. Untuk kriteria tinggi berada pada antara lebih dari $70 \%$ sampai kurang dari sama dengan $100 \%$, kriteria sedang bearada pada lebih dari 50\% sampai kurang dari $70 \%$, dan untuk kriteria rendah berada pada kurang dari sama dengan $50 \%$.

Berdasarkan uraian di atas, secara keseluruhan tingkat kemampuan representasi matematis siswa tergolong sedang dengan skor sebesar 54,6\%. Tingkat kemampuan representasi matematis siswa tergolong sedang karena siswa dapat menyajikan kembali data atau informasi kedalam bentuk tabel atau diagram dan menyusun cerita dan menyatakan suatu pernyataan atau ide matematika dengan katakata atau teks tertulis, akan tetapi siswa kurang dalam menyelesaikan masalah yang melibatkan ekspresi matematis. Sedangkan tingkat kemampuan representasi matematis siswa pada masing-masing kelompok diperoleh data bahwa jumlah persentase siswa kelompok atas lebih tinggi dibanding siswa kelompok tengah dan bawah, dan untuk tingkat kemampuan representasi matematis siswa pada masing-masing indikator diperoleh data bahwa jumlah persentase pada aspek visual lebih tinggi dibanding aspek simbol dan verbal.

\section{Kesalahan Kemampuan Representasi Matematis Siswa}

Pada pembahasan ini akan disajikan dahulu data hasil penelitian berdasarkan hasil kerja siswa kelompok atas, kelompok tengah, dan kelompok bawah. Selanjutnya dari hasil tersebut akan diketahui letak kesalahan dalam menyelesaikan soal kemampuan representasi matematis siswa. Berikut ini merupakan deskripsi jawaban siswa: 
1. Kemampuan representasi matematis siswa kelompok atas

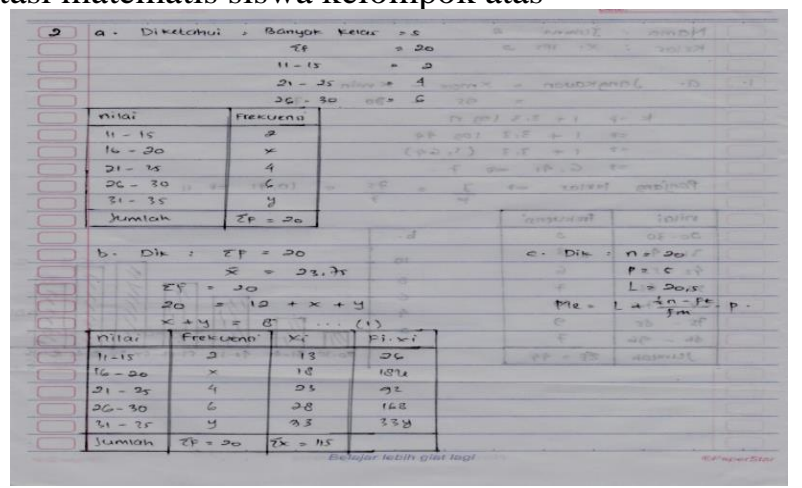

Gambar 2. Kesalahan siswa dalam menyelesaikan soal pada indikator simbol

Dari jawaban siswa (Gambar 2) dapat dilihat bahwa terdapat kesalahan prinsip dimana untuk soal nomor 2a siswa salah dalam penarikan kesimpulan akhir dalam menentukan jawaban akhir soal. Untuk soal $2 \mathrm{~b}$ terdapat kesalahan prinsip dimana siswa tersebut tidak mengetahui aturan-aturan dalam rumus matematika, hanya menuliskan apa yang diketahui dari soal dan dapat membuat suatu persamaan serta dapat membuat tabel distribusi namun tidak dapat menyelesaikannya dengan benar, sedangkan untuk soal nomor $2 \mathrm{c}$ hanya menuliskan apa yang diketahui dan menuliskan rumus mediannya.

2. Kemampuan representasi matematis siswa kelompok tengah
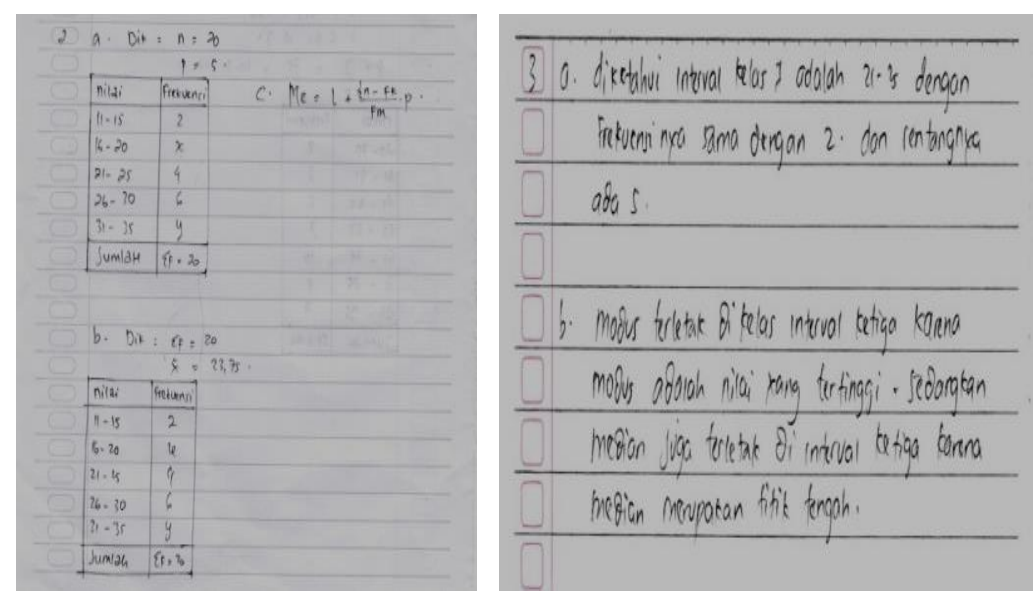

Gambar 3. Kesalahan siswa dalam menyelesaikan soal pada indikator simbol dan verbal

Dari jawaban siswa (Gambar 3) dapat dilihat bahwa terdapat kesalahan prinsip dimana untuk soal 2a,b,c siswa kelompok tengah tidak menuliskan kesimpulan akhir jawaban, tidak mengetahui aturanaturan dalam rumus matematika, hanya menuliskan apa yang diketahui dan menuliskan kembali tabel yang ada pada soal nomor $2 \mathrm{a}$, serta menuliskan rumus mediannya saja, untuk soal nomor 3 terdapat kesalahan prinsip dimana siswa dapat membuat cerita dengan benar dan lengkap, mengetahui letak modus dan median tetapi salah dalam memberikan alasan atau kesimpulan akhir jawaban. 
3. Kemampuan representasi matematis siswa kelompok bawah
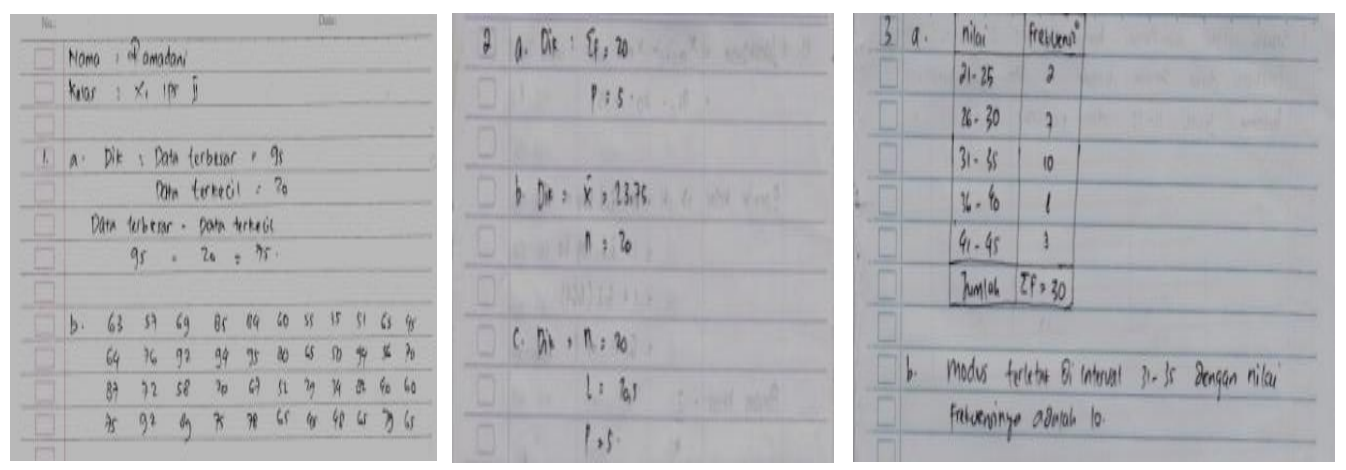

Gambar 4. Kesalahan siswa dalam menyelesaikan soal pada indikator visual, simbol dan verbal

Dari jawaban siswa (Gambar 4) dapat dilihat bahwa terdapat kesalahan prinsip yaitu siswa tidak dapat menyelesaikan soal dengan benar, tidak menuliskan langkah-langkah dalam membuat tabel distribusi frekuensi, dimana hanya menuliskan data terbesar dikurangi data terkecil dan untuk diagram batang hanya menuliskan kembali data yang ada pada soal, Untuk soal nomor 2 terdapat kesalahan konsep dan prinsip dimana siswa tidak memahami apa yang diminta soal, tidak mengetahui rumus median, sehingga tidak dapat menyelesaikan dengan tepat dan benar, hanya menuliskan apa yang diketahui dari soal saja, sedangkan untuk soal nomor 3 terdapat kesalahan prinsip yaitu tidak membuat cerita dari tabel yang ada, hanya menuliskan mengetahui letak modus saja namun tidak memberikan kesimpulan akhir jawaban.

Dari data di atas diketahui bahwa siswa kelompok atas dan kelompok tengah memahami permasalahan yang diberikan, mampu merepresentasikan masalah yang diberikan kedalam bentuk tabel atau diagram, tetapi siswa belum mampu menyelesaikan masalah yang melibatkan ekspresi matematis. Sedangkan kemampuan representasi matematis siswa kelompok bawah mengalami kesulitan dalam memahami permasalahan yang diberikan, kesulitan merepresentasikan masalah yang diberikan kedalam bentuk matematis, dan kesulitan dalam penarikan kesimpulan untuk menentukan jawaban akhir soal. Hal ini Sejalan dengan pendapat Soedaji (dalam Imron, 2014) menyatakan bahwa kesalahan yang dilakukan siswa dalam menyelesaikan soal meliputi kesalahan konsep, kesalahan prinsip, dan kesalahan operasi. Berdasarkan pemaparan di atas dapat disimpulkan bahwa kesalahan konsep disini yaitu siswa tidak memahami soal yang diberikan, kesalahan prinsip yaitu siswa salah dalam menggunakan aturan-aturan dalam rumus matematika dan salah dalam penarikan suatu kesimpulan untuk menentukan jawaban akhir soal, kesalahan operasi yaitu salah dalam melakukan suatu perhitungan baik penjumlahan, pengurangan, pembagian, maupun perkalian.

\section{Faktor yang Mempengaruhi Kesalahan Siswa}

Setelah mengetahui kesalahan representasi matematis siswa pada materi statistika, selanjutnya yang dilakukan adalah mencari tahu faktor yang mempengaruhi kesalahan representasi matematis siswa. Untuk mengetahui faktor yang mempengaruhi kesalahan kemampuan representasi matematis siswa dalam menyelesaikan soal statistika, peneliti melakukan wawancara terhadap keenam subyek tersebut untuk mendapatkan infomasi mengenai faktor yang mempengaruhi kesalahan siswa dalam menyelesaikan soal representasi matematis. 
Untuk kelompok atas pada indikator menyajikan kembali data atau informasi ke dalam bentuk tabel dan diagram siswa kelompok atas dapat menjawab soal dengan benar dalam membuat tabel distribusi frekuensi dengan langkah-langkah yang tepat dan dapat membuat diagram batang dengan benar. Pada indikator penyelesaian masalah yang melibatkan ekspresi matematis terdapat faktor yang mempengaruhi kesalahan yang dilakukan siswa dalam menyelesaikan soal yaitu faktor kesalahan prinsip (tidak mengggunakan aturan-aturan dalam rumus matematika. Pada indikator menyusun cerita dan menyatakan suatu pernyataan atau ide matematika dengan menggunakan kata-kata atau teks tertulis terdapat faktor kesalahan prinsip (tidak memberikan suatu kesimpulan dalam menentukan jawaban akhir soal).

Untuk kelompok tengah pada indikator menyajikan kembali data atau informasi ke dalam bentuk tabel dan diagram terdapat faktor kesalahan konsep (tidak paham dalam membuat diagram batang dari soal yang diberikan). Pada indikator penyelesaian masalah yang melibatkan ekspresi matematis terdapat faktor kesalahan prinsip (tidak menggunakan aturan-aturan dalam rumus matematika serta tidak memberikan suatu kesimpulan dalam menentukan jawaban akhir soal). Pada indikator menyusun cerita dan menyatakan suatu pernyataan atau ide matematika dengan menggunakan kata-kata atau teks tertulis terdapat faktor kesalahan prinsip (tidak memberikan suatu kesimpulan dalam menentukan jawaban akhir soal).

Untuk kelompok bawah pada indikator menyajikan kembali data atau informasi ke dalam bentuk tabel dan diagram terdapat faktor kesalahan prinsip (tidak menggunakan aturan-aturan dalam rumus matematika). Pada indikator penyelesaian masalah yang melibatkan ekspresi matematis terdapat faktor kesalahan konsep dan prinsip (kurang paham terhadap soal yang diteskan dan tidak menggunakan aturan-aturan dalam rumus matematika). Pada indikator menyusun cerita dan menyatakan suatu pernyataan atau ide matematika dengan menggunakan kata-kata atau teks tertulis terdapat faktor kesalahan prinsip (tidak memberikan kesimpulan akhir jawaban).

Hal ini sejalan dengan pendapat Soleh (dalam Sari, 2014) faktor yang mempengaruhi kesalahan siswa dalam menyelesaikan soal disebabkan oleh faktor kognitif meliputi faktor kesalahan konsep, faktor kesalahan prinsip, dan faktor kesalahan operasi. Berdasarkan pemaparan di atas disimpulkan bahwa faktor yang mempengaruhi kesalahan siswa dalam menyelesaikan soal meliputi faktor kesalahan konsep (siswa tidak memahami soal yang diteskan), faktor kesalahan prinsip (tidak menggunakan aturan-aturan dalam rumus matematika dan tidak memberikan kesimpulan akhir jawaban), dan faktor kesalahan operasi (salah dalam melakukan perhitungan baik penjumlahan, pengurangan, pembagian, maupun perkalian).

\section{KESIMPULAN DAN SARAN}

Berdasarkan hasil analisis yang dikemukakan oleh peneliti pada bab IV, maka disimpulkan bahwa kemampuan representasi matematis siswa pada materi statistika kelas XI SMA Negeri 5 Singkawang berdasarkan rumusan masalah sebagai berikut.

Tingkat kemampuan representasi matematis siswa kelas XI SMA Negeri 5 Singkawang secara keselruhan sebesar 54,5\% dengan kategori sedang. Untuk tingkat kemampuan representasi matematis siswa pada aspek visual sebesar 70\% dengan kategori sedang, aspek simbol sebesar $45,1 \%$ dengan kategori rendah, dan aspek verbal sebesar 53,3\% dengan kategori sedang. Sedangkan untuk tingkat kemampuan representasi siswa kelompok atas sebesar 76,1\% dengan kategori tinggi, siswa kelompok tengah sebesar 52,3\%, dan siswa kelompok bawah sebesar35,1\% dengan kategori rendah.

Kesalahan siswa dalam menyelesaikann soal representasi matematis materi statistika kelas XI SMA Negeri 5 Singkawang meliputi kesalahan konsep (salah dalam memahami makna soal), kesalahan prinsip (salah dalam penarikan kesimpulan untuk menentukan jawaban akhir soal, salah dalam 
menggunakan aturan-aturan dalam rumus matematika), kesalahan operasi (salah dalam menggunakan operasi matematika baik penjumlahan, pengurangan, pembagian, maupun perkalian).

Faktor yang mempengaruhi kesalahan siswa dalam menyelesaikan soal representasi matematis materi statistika kelas XI SMA Negeri 5 Singkawang meliputi faktor kesalahan konsep (siswa tidak memahami soal yang di teskan), faktor kesalahan prinsip (siswa salah dalam penarikan kesimpulan untuk menentukan jawaban akhir soal, siswa salah dalam menggunakan aturan-aturan dalam rumus matematika), dan faktor kesalahan operasi (ketidak cermatan menentukan hasil perhitungan baik penjumlahan, pengurangan, pembagian, maupun perkalian).

\section{DAFTAR PUSTAKA}

Abdullah, In Hi (2012). "Peningkatan Kemampuan Representasi Matematis Siswa SMP Melalui Pembelajaran Kontekstual yang Terintegrasi dengan Soft Skill”. Prosiding, FKIP Universitas Khairun.

Buyung, B., \& Nirawati, R. (2018). Pengaruh Karakter Kerja Keras Terhadap Kemampuan Literasi Matematis Siswa Melalui Model Discovery Learning. JPMI (Jurnal Pendidikan Matematika Indonesia), 3(1), 21-25.

Lestari, Kurnia Eka dan Yudhanegara, Mokhammad Ridwan. 2015. Penelitian Pendidikan Matematika. Bandung: PT Refika Aditama.

Lewy. (2009). Pengembangan Soal Untuk Mengukur Kemampuan Berfikir Tingkat Tinggi Pokok Barisan dan Deret Bilangan Di Kelas IX Akselerasi SMP Xaverius Maria Palembang. http://eprints.unsri.ac.id/820/1/2 Lewy 14-28.pdf. diakses tanggal 20 Februari 2014

Mailina, Alfi Saidah (2014). "Analisis Kemampuan Representasi Matematis Siswa dalam Menyelesaikan Soal Matematika Materi Komposisi Fungsi dan Invers Pada Kelas XI IPA 3 MAN Rejotangan". Penelitian, Fakultas Tarbiyah dan Ilmu Keguruan Institut Agama Islam Negeri Tulungagung.

Mariyam, M., Sugianto, S., \& Suratman, D.(2016). Pengembangan Soal Untuk Mengukur Kemampuan Komunikasi dan Translasi Representasi Matematis Siswa Sekolah Menengah Pertama (Doctoral dissertation, Tanjungpura University).

Muthmainah (2014). "Meningkatkan Kemampuan Representasi Matematis Siswa Melalui Pendekatan Pembelajaran Metaphorical Thinking". Penelitian, Fakultas Ilmu Tarbiyah dan Keguruan Universitas Islam Negeri Syarif Hidayatullah.

NCTM. 2000. Principles and Standards for School Mathematics. Reston, VA: NCTM.

Pujiastuti, H. (2008). Pembelajaran Kontekstual Untuk Meningkatkan Kemampuan Koneksi Dan Representasi Siswa SMP. Tesis SPS UPI Bandung.

Sabirin, Muhammad (2014). "Representasi Dalam Pembelajaran Matematika". Jurnal Pendidikan Matematika, IAIN Antasari Banjarmasin. Vol . 01 No. 02 Januari - Juni 2014.

Sari (2014). "Analisis Kesalahan Siswa Kelas VIII SMP BOPKRI 2 Yogyakarta dalam Mengerjakan Soal-Soal Operasi Bentuk Aljabar Tahun Ajaran 2014/2015". Skripsi. Universitas Sanata Dharma Yogyakarta. Dipublikasikan.

Soedjadi, R. (2014). Inti dasar-dasar pendidikan matematika realistik indonesia. Jurnal pendidikan matematika. 1(2), 125-133.

Sugiyono. 2012. Metode Penelitian Pendidikan Pendekatan Kuantitatif, Kualitatif, dan $R \& D$. Bandung: Penerbit Alfabeta.

Susilawati (2014). Analisis Kesulitan Siswa Dalam Menyelesaikan Soal Materi Aljabar Siswa Kelas VIII SMP Negeri 2 Bangil. Skripsi Fakultas Keguruan dan Ilmu Pendidikan. Universitas Jember: Dipublikasikan.

TIMSS. (2011). TIMSS 2011 Internatioal Result In Mathematics. Chestnut Hill: TIMSS dan PIRLS International Study Center.

Walle, John A. Van De. 2008. Matematika Sekolah Dasar dan Menengah : Pengembangan Pengajaran. Jakarta : Airlangga. 